\title{
Impact of Preoperative Analytical Values on Post-Operative Mortality Rate of Intertrochanteric Fractures
}

\author{
Impacto de Valores Analíticos Pré-Operatórios na Taxa de Mortalidade \\ Pós-Operatória de Fraturas Intertrocantéricas
}

\author{
Ana BORGES ${ }^{1}$, João TORRES ${ }^{2}$, Ricardo SÃO SIMÃO², Abel Trigo CABRAL ${ }^{3}$, Rui PINTO² \\ Acta Med Port 2014 Mar-Apr;27(2):218-222
}

\section{ABSTRACT}

Introduction: Intertrochanteric fractures incidence has been increasing over the past few years and therefore so have all the problems associated with it. It is important to search for possible ways to reduce comorbidities as well as postoperative mortality. We decided to assess the impact of some routine pre-operative analytical values on post-operative mortality of patients with inter-trochanteric fractures 65 years or older.

Material and Methods: From all intertrochanteric fracture admissions between January 2007 and May 2012, 160 patients were included in this study. The variables studied were age, gender, length of hospital stay, and analytical data such as hemoglobin, total leucocyte count, platelets, urea, creatinin and plasma sodium. Follow-up data on mortality were obtained from the civil registry and, considering 6 months as the cut-off point, patients were divided into 2 groups based on their survival. Mann-Whitney and Chi square statistics were used to study the association between our variables and patients survival.

Results: Our population showed a median age of 82 years old and a majority of women $(79.4 \%)$. Within the first 6 months after surgery, 27 patients of the initial $160(16.1 \%)$ died. Mortality was associated with low hemoglobin, high platelets, high creatinin and low plasma sodium.

Conclusions: Postoperative mortality of hip surgery is high. Our findings could be used to reduce this rate by correcting some analytical values preoperatively.

Keywords: Hip Fractures/mortality; Postoperative Period.

\section{RESUMO}

Introdução: A incidência das fraturas intertrocantéricas tem aumentado ao longo dos últimos anos, bem como todos os problemas a elas associados. É importante pesquisar possíveis formas de reduzir quer co-morbilidades, quer a mortalidade pós-operatória. Decidimos avaliar o impacto de alguns valores analíticos pré-operatórios na mortalidade pós-operatória de doentes com fractura intertrocantérica, com idade igual ou superior a 65 anos.

Material e Métodos: De todas as fracturas intertrocantéricas admitidas entre Janeiro de 2007 e Maio 2012, 160 doentes foram incluídos no estudo. As variáveis estudadas foram idade, género, tempo de internamento, e dados analíticos, como hemoglobina, contagem de leucócitos e plaquetas, níveis de ureia e creatinina e concentração de sódio plasmática. Informação relativa à mortalidade foi obtida através do registo civil e, considerando um ponto de corte de seis meses após a cirurgia, os doentes foram divididos em dois grupos de acordo com a sua sobrevida. Os testes de Mann-Whitney e Chi-quadrado foram utilizados para estudar a associação entre as nossas variáveis e a sobrevida dos doentes.

Resultados: A nossa população apresentava uma idade mediana de 82 anos de idade e uma maioria de mulheres (79,4\%). Nos primeiros 6 meses após a cirurgia, 27 doentes dos iniciais $160(16,1 \%)$ faleceram. A mortalidade estava relacionada com valores baixos de hemoglobina, elevados de plaquetas, elevados de creatinina e baixa concentração de sódio plasmático.

Conclusão: A taxa de mortalidade pos-operatória da cirurgia da anca é elevada. Os nossos resultados podem ser utilizados para reduzir esta taxa, corrigindo valores analíticos pré-operatórios.

Palavras-chave: Fracturas da Anca/mortalidade; Período Pós-Operatório.

\section{INTRODUCTION}

In the last few years there has been a significant increase of life expectancy, therefore hip fracture incidence is growing. ${ }^{1,2}$ Hip fracture is a major and increasing global public health and financial problem ${ }^{1,3}$ because of the high mortality and morbidity, and all the costs associated with it. The majority of deaths occur during the early period after surgery, up to the first year. ${ }^{4,5}$ Several studies have tried to test different variables with possible impact on postoperative mortality, like age, gender, anemia, data specific to pre-operative analysis, time to surgery, nutritional status and comorbidities. ${ }^{4-10}$
The evaluation of risk factors can help reduce complications as well as post-operative mortality, since some may be corrected before surgery. The majority of studies have included patients with different hip related fracture types: subtrochanteric, intertrochanteric and femoral neck fractures. ${ }^{1,4,11}$ Therefore, we decided to study a more homogenous group of fractures - intertrochanteric fractures - which have a high incidence and high morbidity/ mortality rates, since they are associated with more prolonged bed rest, due to the fact that weight bearing is delayed, compared to femoral neck fractures, usually

\footnotetext{
1. Faculty of Medicine. University of Porto. Porto. Portugal.

2. Department of Orthopedics and Traumatology. Centro Hospitalar de S. João. Porto. Portugal.

3. Department of Orthopedics and Traumatology. Faculty of Medicine. University of Porto. Porto. Portugal.

Recebido: 05 de Julho de 2013 - Aceite: 10 de Outubro de 2013 | Copyright @ Ordem dos Médicos 2014
} 
treated with arthoplasty and not osteosynthesis. According to this, we decided to evaluate the impact of some routine pre-operative analytical data on the post-operative mortality of patients with intertrochanteric fractures, 65 years or older, in order to understand which values could be corrected before the intervention.

\section{MATERIAL AND METHODS}

From January 2007 through May 2012, 198 patients with intertrochanteric fractures were admitted to the Department of Orthopedics and Traumatology, Hospital São João, Porto. The surgical procedures included were internal fixation of the fracture with a DHS system analogue or cervicodiaphisary nailing. Out of these, 20 patients were under 65 years old and were excluded from the study. Using hospital records, it was possible to extract the necessary data for the present study. Patient age, gender, length of hospital stay and analytical data like hemoglobin $(\mathrm{Hb})$, total leucocyte count, platelets, urea, creatinin and sodium, were recorded in this study database. As a consequence of discrepancies in the hospital's database, some data concerning urea and creatinin had to be converted to $\mathrm{mg} /$ $\mathrm{dL}$. Due to lack of information in some cases (analytical data unknown) and queue time for surgery over 10 days, 17 more patients were excluded from the study.

Follow-up data on mortality was obtained from the civil registry on January 10, 2013. Only one patient was excluded because the date of death was not available.

Taking all this in account, 38 patients were excluded from the study and 160 patients remained. These patients were divided into 2 groups based on whether they survived for at least 180 days after the hip fracture or not.
The study was approved by the hospital's ethics committee.

\section{Statistics}

Statistical analysis was performed using the Statistical Package for the Social Sciences version 21.0 program (SPSS Inc, Chicago, IL, USA). Continuous variables are represented by their median (range). We used MannWhitney 2-sample statistics for skewed distributions, to examine the relationship between the various risk factors and outcomes. Values of $p<0.05$ were considered statistically significant.

\section{RESULTS}

At the time of admission, the median of the patients age was 82 years (range $65-98$ years). The majority of the patients were female (79.4\%). 27 of 160 patients (16.1\%) died within 6 months after the surgery (Table 1). All the patients were hospitalized for around 10 (2 - 73) days.

Table 2 summarizes analytical variables according to sex differences and survival time: blood hemoglobin $(\mathrm{g} /$ $\mathrm{dL})$, leucocyte count $\left(10^{\%} / \mathrm{L}\right)$, platelet count $\left(10^{9} / \mathrm{L}\right)$, plasma urea $(\mathrm{mg} / \mathrm{dL})$, plasma creatinin $(\mathrm{mg} / \mathrm{dL})$ and plasma sodium $(\mathrm{mEq} / \mathrm{L})$.

As shown in Table 3, there is statistical significance between the analytical values of hemoglobin (median surv: 11.90 ; median died: $10.90 ; p=0.012$ ), platelet count (median surv: 199; median died: $225 ; p=0.045$ ), creatinin (median surv: 0.94 ; median died: $1.15 ; p=0.045$ ) and plasma sodium (median surv: 138; median died: $136 ; p=$ 0.009); and patient mortality within the following 6 months, accordingly to Mann-Whitney statistics.

Table 1 - Patient characteristics

\begin{tabular}{|c|c|c|c|}
\hline & \multicolumn{3}{|c|}{ Patients } \\
\hline & Total & Survived & Died (until 180 days) \\
\hline & $n=160$ & $n=133(83.1 \%)$ & $n=27(16.1 \%)$ \\
\hline Age, median ( $n$, range) & $82(65-98)$ & $81(65-98)$ & $85(74-95)$ \\
\hline Female & $82(68-98)$ & $82(68-98)$ & $84(78-95)$ \\
\hline Male & $79(65-94)$ & $78(65-94)$ & $87(74-89)$ \\
\hline \multicolumn{4}{|l|}{ Gender, $\boldsymbol{n}(\%)$} \\
\hline Female & $127(79.4 \%)$ & $108(81.2 \%)$ & $19(70.4 \%)$ \\
\hline Male & $33(20.6 \%)$ & $25(18.8 \%)$ & $8(29.6 \%)$ \\
\hline Time in hospital, median ( $n$, range) & $10(2-73)$ & $10(3-55)$ & $9(2-73)$ \\
\hline Female & $11(2-73)$ & $11(3-53)$ & $10(2-73)$ \\
\hline Male & $8(3-55)$ & $8(4-55)$ & $4(3-18)$ \\
\hline
\end{tabular}




\begin{tabular}{|c|c|c|c|}
\hline & \multicolumn{3}{|c|}{ Patients } \\
\hline & Total & Survived & Died (until 180 days) \\
\hline & $n=160$ & $n=133(83.1 \%)$ & $n=27(16.1 \%)$ \\
\hline Blood hemoglobin [g/dL], median ( $n$, range) & $11.70(6.70-15.70)$ & $11.90(7.40-15.70)$ & $10.90(6.70-14.80)$ \\
\hline Female & $11.60(6.70-15.70)$ & $11.70(7.40-15.70)$ & $10.90(6.70-14.60)$ \\
\hline Male & $12.60(8.10-12.40)$ & $12.8(9.10-15.40)$ & $11.10(8.10-14.80)$ \\
\hline Leucocyte count $\left[10^{9} / L\right]$, median ( $n$, range) & $10.94(3.75-40.23)$ & $11.05(3.75-40.23)$ & $9.19(5.84-18.20)$ \\
\hline Female & $19.92(3.75-40.23)$ & $10.99(3.75-40.23)$ & $9.19(5.84-16.92)$ \\
\hline Male & $11.34(5.30$ - 33.49) & $11.44(5.30-33.49)$ & $9.30(7.24-18.20)$ \\
\hline Platelet count [109/L], median ( $n$, range) & $200.50(59-497)$ & $199(59-415)$ & $225(131-497)$ \\
\hline Female & $203(59-497)$ & $201.50(59-409)$ & $245(131-497)$ \\
\hline Male & $181(119-415)$ & $178(119-415)$ & $204(148-362)$ \\
\hline Plasma urea [mg/dL], median ( $n$, range) & $49(10-212)$ & $48(10-212)$ & $52(28-136)$ \\
\hline Female & $49(13-212)$ & $48(13-212)$ & $53(28-136)$ \\
\hline Male & $49(10-94)$ & $47(10-65)$ & $52(39-94)$ \\
\hline Plasma creatinin [mg/dL], median ( $n$, range) & $1(0.50-9.70)$ & $0.94(0.50-9.70)$ & $1.15(0.50-7.40)$ \\
\hline Female & $0.94(0.50-9.70)$ & $0.93(0.50-9.70)$ & $1.30(0.50-7.40)$ \\
\hline Male & $1(0.60-6.81)$ & $1(0.60-1.64)$ & $1.09(0.60-6.81)$ \\
\hline Plasma sodium [mEq/L], median ( $n$, range) & $137(121$ - 163) & $138(121-163)$ & $136(123-140)$ \\
\hline Female & $138(121$ - 163) & $138(121-163)$ & $136(128-140)$ \\
\hline Male & $136(123-142)$ & $137(128-142)$ & $133(123-138)$ \\
\hline
\end{tabular}

\section{DISCUSSION}

Several studies reveal statistical significance between analytical values (hematological and biochemical data) and hip fracture post operative mortality. ${ }^{12-14}$ Our study confirms the relation between simple preoperative analysis and sixmonth post-operative mortality. The median age of our study was 82 years, similarly to other studies.,12,14 Despite not being statistically significant, it's true that the median age is higher on the mortality group, which we can associate with more comorbidities.

Attending to our analytical results, we found an association between hemoglobin, platelet count, plasma creatinin and plasma sodium values and post-operative mortality. Hemoglobin was lower in patients who died within 6 months (median died: 10.90 vs median surv:11.90; $p<0.05$ ), possibly due to the risk of more severe anemia after surgery, since there can be heavy bleeding. Other studies had already stated that low hemoglobin is a strong independent predictor of mortality. ${ }^{15-17}$

We found an association between platelet count and mortality, however, against our expectations, the people who survived had a lower platelet count. We were not able to find a solid correlation, but this discrepancy was already present in another study. ${ }^{14}$ Chin-An et al. found that there was no significant relation between low platelet count and increased mortality. ${ }^{16}$ One possibility might be the fact that platelets are indirect markers of inflammation, a state that is present whenever there is a fracture.

As it has been stated in several other studies, ${ }^{12-14,16}$ plasma creatinin levels correlate significantly with mortality, being higher in those who do not survive the first six months. On our study the median creatinin level was $0.94 \mathrm{mg} / \mathrm{dL}(0.5$ -9.7) for the surviving group, and $1.15 \mathrm{mg} / \mathrm{dL}(0.5-7.4)$ for the other. According to Bjorkelund et al, mortality in patients with higher plasma creatinin levels were almost 3-fold that of the ones with normal levels. Despite this, they stated that plasma creatinine levels are not an independent mortality factor. ${ }^{13}$ However, one might associate higher creatinine levels to dehidratation, a factor that can easily be corrected.

Finally, plasma sodium concentration was lower on the group which died in the first six months, and there was statistical correlation between these values $(136 \mathrm{mEq} / \mathrm{L}$ 
Patients

Survived

Died (until 180 days)

$n=133(83.1 \%)$

$n=27(16.1 \%)$

$p$-value

$0.200^{*}$

Female

Male

Age [years], median ( $n$, range)

Time in hospital [days], median $(n$, range)

Blood hemoglobin [ $/ \mathrm{dL}]$, median ( $n$, range)

Leucocyte count $\left[10^{\%} / L\right]$, median $(n$, range)

Platelet count $\left[10^{9} / \mathrm{L}\right]$, median $(n$, range)

Plasma urea $[\mathrm{mg} / \mathrm{dL}]$, median ( $n$, range)

Plasma creatinin [mg/dL], median ( $n$, range)

Plasma sodium $[\mathrm{mEq} / \mathrm{L}]$, median ( $n$, range)
108

25

$81(33)$

$10(52)$

$11.90(8.30)$

$11.05(36.48)$

$199(356)$

$48(202)$

$0.94(9.20)$

$138(42)$
19

8

$85(21)$

$0.066^{\dagger}$

$9(71)$

$0.136^{\dagger}$

$10.90(8.10)$

$0.012^{\dagger}$

$9.19(12.36)$

$0.205^{\dagger}$

225 (366)

$0.045^{\dagger}$

$52(108)$

$0.169^{\dagger}$

$1.15(6.90)$

$0.045^{\dagger}$

$136(17)$

$0.009^{\dagger}$
* Using Pearson chi-square test; ${ }^{\dagger}$ Using Mann-Whitney U

vs $138 \mathrm{mEq} / \mathrm{L})$. Some studies stated that raised or low serum sodium were associated with higher post-operative mortality. ${ }^{12,14}$ Lewis et al explained that initial hyponatremia increases cumulative mortality of patients that were submitted to hip surgery. ${ }^{12}$ Our results confirm prior findings from this author.

\section{CONCLUSION}

In our study, we found that basic analytical data is associated with postoperative intertrochanteric fracture outcome. Low hemoglobin level and plasma sodium concentration, as well as increased platelet count and plasma creatinin level are associated with increased mortality during the first 6 months after surgery. Based on the results of our study, and the published literature on this subject, all patients over 65 years old can possibly benefit from correction of these analytical values before surgery

\section{REFERENCES}

1. Bergstrom $U$, Jonsson $H$, Gustafson $Y$, Pettersson $U$, Stenlund $H$, Svensson $\mathrm{O}$. The hip fracture incidence curve is shifting to the right. Acta Orthop. 2009;80:520-4.

2. Lonnroos E, Kautiainen H, Karppi P, Huusko T, Hartikainen S, Kiviranta $\mathrm{I}$, et al. Increased incidence of hip fractures. A population based-study in Finland. Bone. 2006;39:623-7.

3. Youm T, Koval KJ, Zuckerman JD. The economic impact of geriatric hip in order to reduce post-operative mortality. Prospective studies are needed to better confirm this hypothesis.

\section{ACKNOWLEDGMENTS}

We acknowledge C. Dias from the Biostatistical and Medical Informatics Centre for Statistical Analysis and I. Carvalho from Hospital São João for data collection; also G. Rosas from the Biotechnology Science School UCP for linguistic revision.

\section{CONFLICTS OF INTEREST}

The authors declare that they do not have any conflicts of interest as far as this article is concerned.

\section{FUNDING SOURCES}

No financial external sources contributed to the elaboration of this article. postoperative mortality of patients with displaced femoral neck fracture. Injury. 2006;37:705-11.

5. Ozturk A, Ozkan Y, Akgoz S, Yalcyn N, Ozdemir RM, Aykut S. The risk factors for mortality in elderly patients with hip fractures: postoperative oneyear results. Singapore Med J. 2010;51:137-43. 
6. Clague JE, Craddock E, Andrew G, Horan MA, Pendleton N. Predictors of outcome following hip fracture. Admission time predicts length of stay and in-hospital mortality. Injury. 2002;33:1-6.

7. Kenzora JE, McCarthy RE, Lowell JD, Sledge CB. Hip fracture mortality. Relation to age, treatment, preoperative illness, time of surgery, and complications. Clin Orthop Relat Res. 1984;(186):45-56.

8. Koval KJ, Maurer SG, Su ET, Aharonoff GB, Zuckerman JD. The effects of nutritional status on outcome after hip fracture. J Orthop Trauma. 1999;13:164-9.

9. Bass E, French DD, Bradham DD, Rubenstein LZ. Risk-adjusted mortality rates of elderly veterans with hip fractures. Ann Epidemiol. 2007; 17:514-9.

10. Pioli G, Barone A, Giusti A, Oliveri M, Pizzonia M, Razzano M, et al. Predictors of mortality after hip fracture: results from 1-year follow-up. Aging Clin Exp Res. 2006;18:381-7.

11. Hernandez JL, Olmos JM, Alonso MA, Gonzalez-Fernandez CR, Martinez J, Pajaron M, et al. Trend in hip fracture epidemiology over a 14year period in a Spanish population. Osteoporos Int. 2006;17:464-70.
12. Lewis JR, Hassan SKZ, Wenn RT, Moran CG. Mortality and serum urea and electrolytes on admission for hip fracture patients. Injury. 2006;37:698704.

13. Bjorkelund KB, Hommel A, Thorngren KG, Lundberg D, Larsson S. Factors at admission associated with 4 months outcome in elderly patients with hip fracture. AANA J. 2009;77:49-58.

14. Mosfeldt M, Pedersen OB, Riis T, Worm HO, Mark S, Jorgensen HL, et al. Value of routine blood tests for prediction of mortality risk in hip fracture patients. Acta Orthop. 2012;83:31-5.

15. Halm EA, Wang JJ, Boockvar K, Penrod J, Silberzweig SB, Magaziner J, et al. The effect of perioperative anemia on clinical and functional outcomes in patients with hip fracture. J Orthop Trauma. 2004;18:369-74.

16. Ho CA, Li CY, Hsieh KS, Chen HF. Factors determining the 1-year survival after operated hip fracture: a hospital-based analysis. J Orthop Sci. 2010;15:30-7.

17. Bhaskar D, Parker MJ. Haematological indices as surrogate markers of factors affecting mortality after hip fracture. Injury 2011;42:178-82. 


\section{Impact of Preoperative Analytical Values on Post-Operative Mortality Rate of Intertrochanteric Fractures \\ Acta Med Port 2014:27:218-222}

Publicado pela Acta Médica Portuguesa, a Revista Científica da Ordem dos Médicos

Av. Almirante Gago Coutinho, 151

1749-084 Lisboa, Portugal.

Tel: +351218428215

E-mail: submissao@actamedicaportuguesa.com

www.actamedicaportuguesa.com

ISSN:0870-399X | e-ISSN: 1646-0758

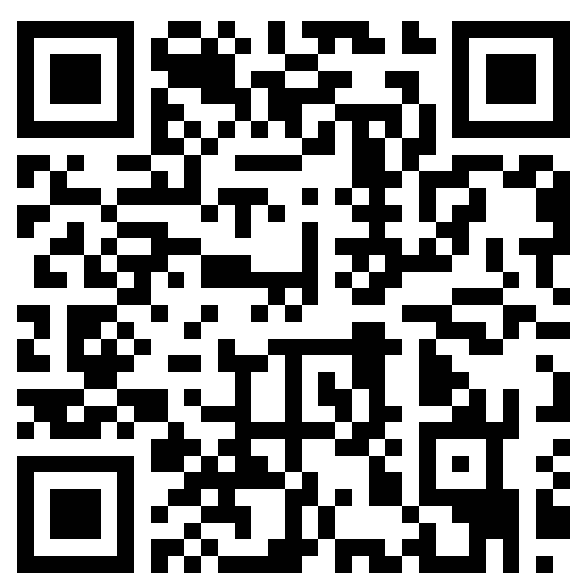

